\title{
NOTARIUSZ JAKO GWARANT BEZPIECZEŃSTWA OBROTU NIERUCHOMOŚCIAMI
}

\begin{abstract}
Zawód notariusza jest zawodem zaufania publicznego, zaś osoba, która wykonuje tę profesję ma obowiązek respektować najwyższe standardy etyczne, jak również być poza wszelkim podejrzeniem, co do swojej bezstronności, co zaś uprawnia do sankcjonowania wszelkich zachowań, stwarzających choćby ryzyko podważania tego zaufania. Wykonując swe obowiązki czuwa nad bezpieczeństwem obrotu prawnego nieruchomościami i w tym zakresie traktowany jest jako tzw. osoba zaufania publicznego. Notariusz nie działa jako mandatariusz żadnej ze stron czynności notarialnej. Notariusz jest jedyną profesją niemającą statusu urzędnika państwowego, którego czynności dokonywane zgodnie z prawem mają charakter dokumentu urzędowego, jednakże żaden ze sporządzonych przez niego dokumentów nie jest jego własnością, a stanowią one własność państwa, zaś notariusz ma jedynie obowiązek ich przechowywania i zabezpieczenia. Notariusz nie świadczy typowej obsługi prawnej, jak np. adwokat, radca prawny, czy doradca podatkowy, a w związku z tym nie łączy go ze stroną czynności prawnej umowny stosunek zobowiązaniowy. Pojawia się zatem pytanie, czy notariusz jako profesjonalista może być gwarantem bezpieczeństwa podczas obrotu nieruchomościami. Bezpieczeństwo bowiem w istocie nadaje jednostce pewności, jakkolwiek pewne ryzyko zagrożeń jest wpisane w każdą z profesji prawniczych. Ustawodawca zatem stworzył takie rozwiązania prawne, aby eliminować w pełni bądź znaczącą ograniczyć ryzyko narażenia na jakąkolwiek szkodę dla potencjalnego klienta notariusza bądź jego mienia.
\end{abstract}

Słowa kluczowe: notariusz, bezpieczeństwo, nieruchomości, gwarant bezpieczeństwa, obrót nieruchomościami.

\section{WPROWADZENIE}

Ochrona prawa własności zagwarantowana jest w Konstytucji Rzeczypospolitej Polskiej z dnia 2 kwietnia 1997 roku$^{2}$. W art. 21 Konstytucji RP wskazano, że RP chroni własność oraz prawo dziedziczenia. W ustawie zasadniczej można też znaleźć wyjątek od tej zasady (wywłaszczenie), który potwierdza jej znaczenie w demokratycznym państwie prawa, jakim w świetle ustawy zasadniczej jest RP. Poza tym art. 21 Konstytucji RP traktuje prawo własności i prawo jej dziedziczenia jako jedną z podstawowych zasad ustroju

\footnotetext{
${ }^{1}$ Dr Norbert Malec, adiunkt w Instytucie Edukacji Uniwersytetu Przyrodniczo-Humanistycznego w Siedlcach; e-mail: norbert.malec@uph.edu.pl.

Norbert Malec, PhD, Siedlce University of natural Science and Humanities, Faculty of Humanities, Stanisława Konarskiego 2, 08-110 Siedlce; e-mail: norbert.malec@uph.edu.pl.

${ }^{2}$ Dz.U. nr 78, poz. 483 z późn. zm. (dalej jako: Konstytucja RP).
} 
gospodarczego państwa. Z kolei w art. 64 Konstytucji RP ustawodawca zagwarantował prawo własności jako jedno z podstawowych praw ekonomicznych każdego człowieka ${ }^{3}$.

Natomiast prawo cywilne stanowi jedną z podstawowych gałęzi w polskim systemie prawa. Wśród przepisów prawa cywilnego znajduje się grupa przepisów poświęcona tematyce własności, w tym nieruchomości. Podstawą jest tytuł III kodeksu cywilnego „Mienie”, którym, zgodnie z art. 44 tego kodeksu jest własność i inne prawa rzeczowe ${ }^{4}$.

Prawo własności dotyczy rzeczy, którymi w myśl powołanego kodeksu są tylko rzeczy materialne (art.45), a wśród nich ważne miejsce zajmują nieruchomości. Są to części powierzchni ziemskiej stanowiące odrębny przedmiot własności (grunty), jak również budynki trwale z gruntem związane lub części takich budynków, jeżeli na mocy przepisów szczególnych stanowią odrębny od gruntu przedmiot własności. ${ }^{5}$

\section{ZASADA SWOBODNEGO DYSPONOWANIA WŁASNOŚCIA I JEJ OGRANICZENIA W ODNIESIENIU DO NIERUCHOMOŚCI}

Prawo własności jest prawem zbywalnym. Art. $57 \S 1$ k.c. stanowi, iż nie można przez czynność prawną wyłączyć ani ograniczyć uprawnienia do przeniesienia, obciążenia, zmiany lub zniesienia prawa, jeżeli według ustawy prawo to jest zbywalne. Większość praw majątkowych w sferze prawa cywilnego ma charakter praw zbywalnych, co oznacza, że mogą być w drodze odpowiednich czynności prawnych przenoszone z jednego podmiotu prawnego na inny podmiot prawny. Wyjątki od tej zasady ustanowione są zarówno w przepisach kodeksu cywilnego, jak i ustawach szczególnych ${ }^{6}$.

Zgodnie z art. 140 k.c., umieszczonego na czele przepisów działu II kodeksu cywilnego „Treść i wykonywanie własności”, w granicach określonych przez ustawy i zasady współżycia społecznego właściciel może, z wyłączeniem innych osób, korzystać z rzeczy zgodnie ze społeczno-gospodarczym przeznaczeniem swego prawa, w szczególności może pobierać pożytki i inne dochody z rzeczy. W tych samych granicach może rozporządzać rzeczą. Prawo rozporządzania rzeczą, w omawianym w niniejszej pracy przypad$\mathrm{ku}$ - nieruchomością, przez właściciela zostało jednak obwarowane pewnymi wymogami. Niektórym czynnościom prawnym ustawodawca narzuca $\mathrm{z}$ góry formę ich dokonania, innym pozostawiając swobodę wyboru formy przez strony i innych uczestników czynności. Z taką sytuacją przymusu formy, stanowiącą swoiste ograniczenie w swobodzie dysponowania własnością, mamy do czynienia w sytuacji rozporządzania nieruchomością.

Do problematyki formy dokonywania czynności prawnych wprowadza nas art. 73 k.c., zgodnie z którym, jeżeli ustawa zastrzega dla czynności prawnej formę pisemną, czynność dokonana bez zachowania zastrzeżonej formy jest nieważna tylko wtedy, gdy ustawa przewiduje rygor nieważności. Przechodząc do meritum - tak właśnie jest w przypadku czynności rozporządzających mających za przedmiot nieruchomość. Otóż zgodnie z art. 158 kodeksu cywilnego umowa zobowiązująca do przeniesienia własności nieruchomości powinna być zawarta w formie aktu notarialnego. To samo dotyczy umowy przenoszącej własność, która zostaje zawarta w celu wykonania istniejącego uprzednio zobowiązania

3 W. Skrzydło, Konstytucja Rzeczypospolitej Polskiej. Komentarz, LEX nr 144810.

${ }^{4}$ Art. 44 ustawy z dnia 1 stycznia 1965 r. Kodeks cywilny (Dz.U. z 2014 r., poz. 121 ze zm.) (dalej jako: k.c.).

5 Art. 46 k.c.

${ }^{6}$ K. Piasecki, Kodeks cywilny. Komentarz. Księga pierwsza. Część ogólna, LEX nr 77375. 
do przeniesienia własności nieruchomości; zobowiązanie powinno być w akcie wymienione. Uzasadnieniem wymogu formy notarialnej dla tego rodzaju czynności prawnych jest niewątpliwie dążenie ustawodawcy do zabezpieczenia interesu społecznego oraz interesu kontrahentów i osób trzecich?

Interes społeczny związany jest zarówno ze znaczeniem nieruchomości dla państwa, jak również zabezpieczeniem interesów stron umowy. Akt notarialny, wraz z odpisem księgi wieczystej, stanowi wiarygodny dokument urzędowy, potwierdzający kto jest właścicielem danej nieruchomości (zwłaszcza, że przypadki, w których nieruchomość nie ma założonej księgi wieczystej nie są wcale rzadkie w praktyce notarialnej).

Według normy przepisu art. 158 k.c. formy aktu notarialnego wymaga umowa zobowiązująca do przeniesienia własności nieruchomości, to jest zarówno o umowa zobowiązująca, która równocześnie przenosi własność, jak też o umowa o charakterze wyłącznie zobowiązującym; nie wymagają formy aktu notarialnego pod rygorem nieważności w reżimie art. 158 k.c. w zw. z art. 73 § 2 k.c. - umowy służące organizacji obrotu nieruchomościami, jeżeli nie mają równocześnie ściślejszego charakteru umów zobowiązujących do przeniesienia własności ${ }^{8}$.

Najbardziej powszechnym przykładem takiej umowy, często występującym w praktyce notarialnej, jest umowa przedwstępna sprzedaży (może być również zamiany, darowizny etc.). Należy jednak zauważyć, że przymus notarialny nie ogranicza się jedynie do przymusu formy czynności notarialnej. Przymus ten stanowi instytucjonalną gwarancję funkcjonowania notariatu, a notariusza sytuuje jako funkcjonariusza publicznego, osobę urzędową obligowaną z mocy prawa do dokonywania określonych ustawą czynności notarialnych ${ }^{9}$.

\section{NOTARIUSZ JAKO ,OSOBA ZAUFANIA PUBLICZNEGO” - FUNKCJONARIUSZ PAŃSTWOWY, URZĘDNIK I PRZEDSIĘBIORCA}

W rozważaniach na temat osoby notariusza, jako tego, który czuwa nad bezpieczeństwem obrotu prawnego nieruchomościami nie sposób nie zatrzymać się nad określeniem notariusza jako tzw. osoby zaufania publicznego. Każdy intuicyjnie orientuje się, jaki ciężar gatunkowy mieści w sobie to określenie, jednakże próba jego ścisłego zdefiniowania nastręcza już nieco trudności. Pewne sprecyzowanie tego, czy jest w myśl ustawy owa „osoba zaufania publicznego” znajdziemy w postanowieniu SN z dnia 12 marca 2013 r. wydanym w związku z postępowaniem dyscyplinarnym wszczętym przeciwko notariuszowi, który „uchybił godności i powadze zawodu notariusza w ten sposób, że nie poinformował Rady Izby Notarialnej w formalny sposób, iż po rozpoczęciu wykonywania zawodu notariusza nadal był wspólnikiem spółki cywilnej”.

Zgodnie z tym orzeczeniem, zawód notariusza jest zawodem zaufania publicznego i osoba wykonująca tę profesję zobowiązana jest respektować najwyższe standardy etyczne i być poza wszelkim podejrzeniem co do swojej bezstronności, co uprawnia do sank-

\footnotetext{
${ }^{7}$ E. Gniewek, Kodeks cywilny. Księga druga. Wtasność i inne prawa rzeczowe. Komentarz (do art. 158 kodeksu cywilnego), LEX 73505.

8 Tamże.

9 A. Oleszko, Prawo o notariacie. Komentarz, Warszawa 2016, s. 117.
} 
cjonowania wszelkich zachowań, stwarzających choćby ryzyko podważania tego zaufania ${ }^{10}$.

Zdaniem A. Oleszki sformułowanie „osoba zaufania publicznego” jest nie tylko zwrotem niedookreślonym, ale nazwa ta nie ma żadnego znaczenia prawniczego. Dalej autor ten twierdzi, że przyznanie notariuszowi statusu osoby zaufania publicznego wynika $\mathrm{z}$ realizacji przez ten urząd funkcji publicznych państwa [choć prowadzi swoistą działalność gospodarczą, z której czerpie dochód - przyp. aut.]. W ślad za poglądami reprezentowanymi w doktrynie uznaje on, iż w przeciwieństwie do innych podmiotów pozarządowej ochrony prawnej (adwokatów, radców prawnych) notariusz nie działa jako mandatariusz żadnej ze stron czynności notarialnej. Notariusz jest jedyną profesją, niemającą statusu urzędnika państwowego, którego czynności dokonywane zgodnie z prawem mają charakter dokumentu urzędowego, jednakże żaden ze sporządzonych przez niego dokumentów nie jest jego własnością, a stanowią one własność państwa, zaś notariusz ma jedynie obowiązek ich przechowywania i zabezpieczenia ${ }^{11}$. Poza tym notariusz nie świadczy typowej obsługi prawnej, jak np. adwokat i w związku z tym nie łączy go ze stroną czynności umowny stosunek zobowiązaniowy. A. Oleszko przypomina również o podkreślanej w doktrynie funkcji jurysdykcji prewencyjnej notariusza, a więc o eliminowaniu lub ograniczaniu ryzyka przyszłego sporu przed sądem oraz jego usprawnienie przez dostarczenie jednoznacznych dowodów, podkreślając jednocześnie, że funkcja ta stanowi istotę notariatu i jest działalnością państwową ${ }^{12}$.

Wydaje się, że takie ujęcie najpełniej pozwala zorientować się, jakie znaczenie ma status notariusza jako osoby zaufania publicznego, choć i tak nie pozwala pozbyć się wątpliwości interpretacyjnych i mnogości poglądów dotyczących interpretacji tego określenia, które zawsze będą się pojawiały na gruncie obecnie obowiązujących regulacji. Abstrahując jednak od teoretycznych sporów i definicji tego pojęcia, należy, podsumowując zagadnienie, stwierdzić, że nie jest ono tylko pustym zwrotem niemającym dla praktyki istotnego znaczenia, ale mieści w sobie kwintesencję funkcji notariusza, jako czuwającego nad bezpieczeństwem obrotu, to jest: jurysdykcji prewencyjnej, publicznego charakteru działalności notariusza oraz jego odmienności od typowych organów obsługi prawnej, a co za tym idzie - bezstronności. Punktem wyjścia do dalszych na ten temat rozważań jest art. 1 § 1 ustawy z dnia 14 lutego 2014 roku Prawo o notariacie, zgodnie z którym notariusz jest powołany do dokonywania czynności, którym strony są obowiązane lub pragną nadać formę notarialną (czynności notarialnych). Art. $2 \S 1$ cytowanej ustawy stanowi zaś, że notariusz w zakresie swoich uprawnień działa jako osoba zaufania publicznego, korzystając z ochrony przysługującej funkcjonariuszom publicznym ${ }^{13}$.

Na wstępie należy zauważyć, że spór co do tego, czy notariusz jest funkcjonariuszem publicznym ma niewielkie znaczenie praktyczne, niemniej jednak z zagadnieniem tym związane są pewne elementy działalności notariusza bezpośrednio związane $\mathrm{z}$ bezpieczeństwem obrotu nieruchomościami. W literaturze przedmiotu nikt nie kwestionuje funkcji publicznych notariatu, ale już co do jednoznacznego określenia notariusza jako

${ }^{10}$ Postanowienie Sądu Najwyższego z dnia 12 marca 2013 roku, SDI 3/13, LEX nr 1418779.

11 A. Oleszko, Prawo..., s. 87.

12 Tamże, s. 87-89.

13 Art. 1 i 2 ustawy z dnia 14 lutego 2014 roku Prawo notariacie (Dz.U. z 2014 r. poz. 164 ze zm.) (dalej jako: u.p.n.). 
funkcjonariusza publicznego nie ma zgody ${ }^{14}$. Notariusz jest funkcjonariuszem publicznym w tym znaczeniu, że będąc osobą zaufania publicznego, wykonuje zadania powierzone przez państwo. Podzielam takie zapatrywanie, ponieważ ujmuje sedno problemu i jest skorelowane $\mathrm{z}$ obowiązującymi przepisami. W zakresie niniejszego opracowania może zainteresować nas ewentualnie wspomniana realizacja funkcji publicznych, bowiem w jej zakres wchodzi szereg obowiązków notariusza powiązanych z bezpieczeństwem obrotu nieruchomościami w szerokim ujęciu. W wyroku z dnia 10 grudnia 2003 r. Trybunał Konstytucyjny uznał, że pozycja notariusza różni się od podmiotów świadczących typowe usługi prawnicze - adwokatów, radców prawnych czy doradców podatkowych. Notariusz jest nie tylko osobą zaufania publicznego, ale pełni jednocześnie funkcje pomocnicze w stosunku do wymiaru sprawiedliwości. Z punktu widzenia przepisów prawnokarnych jest traktowany jako funkcjonariusz publiczny (art. $115 \S 13$ pkt 3 k.k.) i korzysta z ochrony przysługującej funkcjonariuszom publicznym (art. $2 \S 1$ u.p.n.). Notariusz wykonuje także z istoty rzeczy szereg czynności o charakterze urzędowym, m.in. jako płatnik na podstawie odrębnych przepisów pobiera podatki i opłaty skarbowe (art. 7 u.p.n.). Nadto, zgodne z art. $92 \S 4$ u.p.n., notariusz ma obowiązek wysłać do sądu prowadzącego księgę wieczystą nieruchomości akt notarialny obejmujący wniosek skierowany do tego sądu oraz pobiera opłatę sądową od wnioskodawców i przekazuje ją na rachunek bankowy sądu ${ }^{15}$.

Notariusz jest również określany obecnie przedsiębiorcą. Ustawa z dnia 2 lipca 2004 roku o swobodzie działalności gospodarczej objęła swym zakresem również notariuszy. Otóż zgodnie z art. 2 tejże ustawy działalnością gospodarczą jest także działalność zawodowa, wykonywana w sposób zorganizowany i ciągły. Uznano więc, że notariusz prowadzi działalność gospodarczą i jest przedsiębiorcą i to nie tylko na gruncie tej ustawy ${ }^{16}$.

Jednak, zdaniem A. Oleszki, to nie prawo gospodarcze ma wyznaczać status prawnoustrojowy notariatu i notariusza, gdy nawet ustawodawca wprowadza częściowe rozwiązania w tej dziedzinie prawa, a ustrój notariatu oraz stanowisko notariusza mogą określać tylko przepisy o charakterze ustrojowym zamieszczone w prawie o notariacie, a nie w jakiejkolwiek innej ustawie. Zdaniem tego autora, dokonywanie czynności notarialnych jest określonym przez prawo o notariacie przejawem działalności państwa przekazanej i powołanej przez to państwo instytucji notariatu, a nie jakąkolwiek działalnością gospodarczą. Nadto działalność notariusza dokonywana jest nie tylko w interesie prywatnym, ale także w interesie publicznym jako gwaranta bezpieczeństwa obrotu, pełniąc w imieniu państwa funkcję prewencyjną [opisaną powyżej - przyp. aut.]. Notariusz nie reprezentuje jednak ani nie chroni żadnego interesu prywatnego stron, który mógłby być sprzeczny z obowiązującą go zasadą bezstronności. Funkcje usługowe notariusza zaś wyrażają się w zakresie dostępności do siedzib kancelarii oraz pobierania przez notariusza wynagrodzenia ${ }^{17}$. W tym miejscu warto przywołać jeszcze art. 8 u.p.n., który stanowi, iż notariusz używa pieczęci z wizerunkiem orła. Na koniec warto wspomnieć o jednej z najważniejszych zasad działania notariusza - zasadzie bezstronności. Ta prawidłowo rozumiana i poprawnie praktykowana zasada ma fundamentalne znaczenie dla bezpieczeństwa obrotu prawnego dokonywanego w kancelarii notarialnej, bowiem strony kontraktu mogą,

\footnotetext{
${ }^{14}$ A. Oleszko, Prawo..., s. 93-94.

${ }^{15}$ Wyrok TK z dnia 10 grudnia 2003 roku, K 49/01, OTK ZU 2003 nr 9a, poz. 101.

${ }^{16}$ A. Oleszko, Prawo..., s. 101.

17 Tamże, s. 101-102.
} 
z założenia, spodziewać się, że rejent, zobowiązany do tego przez przepisy ustawy i normy etyczne, będzie dążył do zabezpieczenia interesów każdej ze stron i ukształtuje stosunek cywilnoprawny na zasadzie równowagi praw i obowiązków jego uczestników. Zasada ta ma szczególne znaczenie praktyczne. Nierzadko zdarzają się sytuacje, w których jedna ze stron pragnie przeforsować podpisanie kontraktu w formie przez nią zaproponowanej i dla niej korzystniejszej. Mimo nawet tego, że druga strona, często nieświadoma tej nierówności, godzi się na zawarcie umowy na gorszych warunkach, to i tak uważam, że notariusz nie może pozwolić, aby taki akt notarialny doszedł do skutku. Powinien natomiast jak najbardziej proponować stronom takie rozwiązania, które doprowadzą do równego ukształtowania i zabezpieczenia ich sytuacji prawnej. Jest to istotne, zwłaszcza że często zdarza się, iż jedna ze stron ma wsparcie prawnicze w osobie fachowego doradcy np. adwokata lub jest z założenia podmiotem startującym z mocniejszej pozycji rynkowej (np. jest to prężnie działający przedsiębiorca, wspierany przez wykwalifikowany dział prawny). Z mojego doświadczenia zawodowego wynika, że takie przypadki pojawiają się dość często, a notariusz niejednokrotnie musi wykazać się sporą dozą cierpliwości i dyplomacji, aby zarazem zadowolić „dominującego” klienta, jak i pozostać w zgodzie Z postulatem czuwania nad równowagą interesów stron. $\mathrm{Z}$ mojego punku widzenia ten właśnie aspekt przedstawionej zasady ma największe znaczenia praktyczne. Przechodząc natomiast do przedstawienia zasady bezstronności notariusza, z punku widzenia obowiązujących przepisów i poglądów, które zrodziły się na ich tle, uzyskuje ona dodatkowe zabezpieczenie w art. 84 u.p.n., który wprowadza zakaz sporządzania czynności które dotyczą samego notariusza, zastępcy notariusza oraz jego małżonka, krewnych lub powinowatych notariusza w linii prostej bez ograniczenia stopnia, a linii bocznej krewnych i powinowatych do trzeciego stopnia włącznie, osób związanych z notariuszem z tytułu przysposobienia, opieki, kurateli lub będących w bliskim z nim stosunku (również po ustaniu tych relacji). Ten zakaz, ukształtowany podobnie jak w przypadku sędziów, odnosi się do roli notariusza jako tzw. sędziego bez sporu i należy potraktować go na zasadzie wykładni celowościowej, rozszerzająco, aby przeciwdziałał zarzutom niezachowania przez notariusza bezstronności ${ }^{18}$. Jako ciekawostkę pragnę jeszcze przywołać uchwałę Sądu Najwyższego z dnia 2 grudnia 1994 roku. Otóż zgodnie z jej uzasadnieniem, w sytuacji, w której notariusz prawomocnie skazany za składania fałszywych oświadczeń sporządziłby testament notarialny, to wówczas zastosowanie znalazłaby regulacja dotycząca wyłączenia świadków testamentu, wobec czego taki testament należałoby uznać za nieważny, nawet gdyby testator nie wiedział o skazaniu ${ }^{19}$.

\section{ZARYS KSZTALTOWANIA SIE NOTARIATU NA ŚWIECIE I W POLSCE}

Historia notariatu sięga czasów tak odległych, że spokojnie obroni się stwierdzenie, iż instytucja notariusza powstaje niemalże wraz z początkiem pierwszych, rozwiniętych cywilizacji starożytnych. W tym miejscu mogę jedynie stwierdzić, że choć w odmiennym kształcie od dzisiejszego, już od najdawniejszych czasów notariusz spełnia bardzo ważną i przydatną funkcję nie tylko w zakresie spisywania oświadczeń prawnych obywateli i uwierzytelniania dokumentów, ale też, patrząc z perspektywy kolejnych stuleci, wchodzi w skład wykształconej elity narodów, mając swój udział, poza typowymi czynnościami

\footnotetext{
18 Tamże, s. 125.

${ }^{19}$ Uchwała SN z dnia 2 grudnia 1994 roku, III CZP 152/94, OSNC 1998, nr 5 poz. 76.
} 
notarialnymi, również w edukacji, życiu kulturalnym, szerzeniu znajomości prawa i rozwoju społeczeństwa.

W tym miejscu możemy postawić sobie pytanie: skąd w ogóle wzięła się instytucja notariusza? Otóż historia tego zawodu sięga starożytności. Kultura prawa pisanego wywodzi się ze starożytnego Wschodu, z państw starożytnej Mezopotamii oraz z Grecji i państw helleńskich (choć sama nazwa notariusz jest pochodzenia łacińskiego). Notariusz jako spisujący akty prawne, cieszące się rękojmią wiary publicznej, ma swoje źródło tradycji hellenistycznej, obejmującej z czasem także wschodnie obszary imperium rzymskiego. Tam, na gruncie bardzo dobrego systemu prawa rzymskiego, powstał prototyp późniejszego europejskiego notariusza. Pierwszego notariusza w Rzymie spotkać możemy około III wieku n.e., zwany on był tabeliones od spisywania aktów notarialnych na drewnianych tabliczkach ${ }^{20}$.

Nowożytna instytucja notariusza pojawiła się w XII-XIV-wiecznych miastach włoskich, głównie w związu z rozwojem kapitalizmu i renesansem prawa rzymskiego. Wtedy właśnie wykształciła się pozycja notariusza jako osoby zaufania publicznego, gwarantującego pewność i fachowość sporządzanych aktów prawnych, korzystających z wiary publicznej i szczególnej mocy dowodowej, a za notariuszem i jego czynnościami staje autorytet władzy państwowej. Nie wchodząc w szczegóły, wymienić można notariuszy $\mathrm{z}$ mianowania papieskiego oraz z upoważnienia cesarskiego (uprawnienia do ich mianowania przekazywano później na niższe szczeble kościelne i państwowe). Upoważnione do tego były również uniwersytety (przede wszystkim włoskie), a w Polsce były to np. Akademia Krakowska oraz Akademia Zamojska, zaś dalszy rozwój instytucji notariatu tzw. łacińskiego dokonywał się na gruncie prawa rzymskiego i kanonicznego. Funkcje notarialne sprawowali właśnie notariusze papiescy bądź cesarscy.

W Polsce jednak początkowo sytuacja była odmienna, bowiem nazwą rejenta czy później notariusza obejmowano wszystkie osoby przyjmujące oświadczenia i sporządzające stosowne wpisy kancelaryjne oraz dokumenty np. sędziów czy pisarzy sądowych, a nawet tych, którzy z funkcją notariusza nie mieli nic wspólnego, np. sekretarzy czy doradców w prawie, a państwo nie było zainteresowane rozwojem notariatu. Pierwszy akt notarialny w Polsce został sporządzony przez notariusza Budzisława w Kancelarii Arcybiskupa w 1287 roku. Rejent powstał na gruncie praktyki kancelaryjnej urzędów dawnej Polski na przełomie XVI i XVII wieku, a umocniony został w ustawach hipotecznych z 1818 i 1825 roku. Właściwa funkcja notariusza ukształtowana została ostatecznie w Polsce na gruncie ustawodawstwa państw obcych, w szczególności prawa francuskiego, wprowadzonego w 1808 r. najpierw do Księstwa Warszawskiego, a następnie Królestwa Polskiego. Wtedy pojawiła się urzędowa nazwa notariusz i notariat. Tą drogą, głównie przez prawo francuskie, Polska przejęła model notariatu łacińskiego, ale własne prawo notarialne, po wcześniejszych projektach, stworzone zostało dopiero w 1933 roku. Różniło się ono jednak od obecnie obowiązującej regulacji. Przykładowo notariat ten pozbawiony był samodzielności samorządowej $\mathrm{i} \mathrm{w}$ pełni został podporządkowany ministrowi sprawiedliwości. Nadto art. 1 rozporządzenia z 1933 r. jednoznacznie określał status notariusza jako funkcjonariusza publicznego, co jednak nie spowodowało jednoznaczności w interpretacji tego pojęcia, wręcz przeciwnie. Nie analizując szczegółów, przeważa pogląd, że w świetle tej regulacji nie można uznać notariusza za urzędnika państwowego ${ }^{21}$.

\footnotetext{
${ }^{20}$ M. Kuryłowicz, Chirographa i syngrapha, ,Rejent” 1994, nr 10, s. 12-25.
}

${ }^{21}$ A. Oleszko, Prawo..., s. 81. 
Z podobnymi wątpliwościami interpretacyjnymi statusu notariusza, na gruncie obecnej ustawy, mamy do czynienia do dziś. W dniu 1 stycznia 1952 roku weszła w życie uchwalona w dniu 25 maja 1951 r. ustawa - Prawo o notariacie. Zakładała ona zakończenie funkcji tradycyjnego notariatu polegającego przede wszystkim na dokumentowaniu obrotu nieruchomościami oraz czynności z zakresu prawa handlowego. Notariat stał się państwowym organem działającym w formie państwowych biur notarialnych, notariusze zaś stali się pracownikami państwowymi, mianowanymi przez ministra sprawiedliwości, a na czele biur notarialnych stali wyznaczenia także przez niego kierownicy. Zniesiony został w całości samorząd a jego majątek przejęło państwo ${ }^{22}$. W ten sposób, w kontekście zmian politycznych i ustrojowych, próbowano oderwać prawo polskie od kultury prawnej Europy Zachodniej i dostosować ją do nowych wartości socjalistycznych, na gruncie koncepcji systemu praw socjalistycznych (będącej w opozycji do systemu romanistycznego, opartego na tradycji prawa rzymskiego $)^{23}$.

Należy podkreślić, że w państwie socjalistycznym prywatnej własności właściwie nie było, więc obrót nieruchomościami praktycznie nie istniał, a rola notariusza sprowadzała się tylko do poświadczenia podpisów osób zainteresowanych w drugorzędnych, często wręcz wymyślanych czynnościach ${ }^{24}$.

Generalnie państwo socjalistycznie starało się umniejszyć rolę notariatu, jednakże, z powodu niewydolności sądów, powierzono notariatowi wiele zadań z dziedziny sądownictwa, zupełnie niezwiązanych z jego podstawową funkcją, np. sporządzanie oświadczeń o przyjęciu lub odrzuceniu spadku w postępowaniu spadkowym. W latach 60. XX wieku państwowe biura notarialne przejęły od będących w stanie zapaści sądów prowadzenie ksiąg wieczystych. Choć państwo starało się deprecjonować rolę ksiąg wieczystych, poprzez wiele ustaw które miały pozbawić je mocy prawnej, to trzeba zaznaczyć, że zachowanie przez księgi swojej aktualności i znaczenia jako gwaranta bezpiecznego obrotu nieruchomościami i pełnienie przez nie swojej podstawowej funkcji jest w dużej mierze zasługą notariuszy pracujących w państwowych biurach notarialnych ${ }^{25}$. Dopiero przeobrażenia społeczne, polityczne i gospodarcze, które zaczęły zachodzić w Polsce z początkiem lat 80 . XX wieku, pozwoliły na przebudowę polskiego notariatu. W dniu 24 maja 1989 roku zostało uchwalone nowe prawo o notariacie, które umożliwiło tworzenie, obok państwowych biur notarialnych, indywidualnych kancelarii notarialnych. Jednakże już w dniu 14 lutego 1991 roku została uchwalona kolejna ustawa, która zniosła państwowy notariat, a dokonywanie czynności notarialnych powierzyła jedynie notariuszom prowadzącym prywatne kancelarie ${ }^{26}$. Swój obecny kształt notariat polski zawdzięcza więc ustawie z 1991 roku, która obowiązuje do dziś.

\section{AKT NOTARIALNY JAKO DOKUMENT POCHODZĄCY OD NOTARIUSZA}

Do tej tematyki wprowadza nas art. 91 Prawa o notariacie, który stanowi, że notariusz sporządza akt notarialny, jeżeli wymaga tego przepis prawa lub taka jest wola stron.

\footnotetext{
22 A. Urbanik, Reprywatyzacja notariatu 2011, „Rejent”, listopad 2011 (jubileusz 20-lecia miesięcznika, wydanie specjalne), s. 186.

${ }^{23}$ Tamże, s. 187.

24 Tamże, s. 187.

25 Tamże, s. $187-188$.

${ }^{26}$ Z. Truszkiewicz, W sprawie przyszłości notariatu - kilka refleksji, „, Rejent”, marzec 2013, s. 101.
} 
Z kolei art. 92 Prawa o notariacie wymienia elementy konieczne aktu notarialnego. Zgodnie z tym przepisem, akt notarialny powinien zawierać dzień, miesiąc i rok sporządzenia aktu, a w razie potrzeby lub na żądanie strony - godzinę i minutę rozpoczęcia i podpisania aktu, miejsce sporządzenia aktu, imię, nazwisko i siedzibę kancelarii notariusza, a jeżeli akt sporządziła osoba wyznaczona do zastępstwa notariusza lub upoważniona do dokonywania czynności notarialnych - nadto imię i nazwisko tej osoby, imiona, nazwiska, imiona rodziców i miejsce zamieszkania osób fizycznych, nazwę i siedzibę osób prawnych lub innych podmiotów biorących udział w akcie, imiona, nazwiska i miejsce zamieszkania osób działających w imieniu osób prawnych, ich przedstawicieli lub pełnomocników, a także innych osób obecnych przy sporządzaniu aktu, oświadczenia stron, $\mathrm{z}$ powołaniem się $\mathrm{w}$ razie potrzeby na okazane przy akcie dokumenty, stwierdzenie, na żądanie stron, faktów i istotnych okoliczności, które zaszły przy spisywaniu aktu, stwierdzenie, że akt został odczytany, przyjęty i podpisany, podpisy biorących udział w akcie oraz osób obecnych przy sporządzaniu aktu oraz podpis notariusza.

Wymienione elementy aktu notarialnego są niezbędne w tym sensie, że dokument, który ich nie zawiera, nie może być uznany w świetle prawa za akt notarialny. Przykładowo, zgodnie z wyrokiem Sądu Apelacyjnego w Katowicach z dnia 8 stycznia 2014 r., wśród istotnych (konstrukcyjnych) składników aktu notarialnego znajduje się wymóg wymienienia $\mathrm{w}$ akcie notarialnym rzeczywistego imienia i nazwiska osoby składającej oświadczenie, niezbędny jest także podpis tej osoby (art. $92 \S 1$ pkt 4 i 8 u.p.n.). Złożenie oświadczenia przez osobę działającą pod fałszywym nazwiskiem i złożenie przez nią tym samym sfałszowanego podpisu stanowi naruszenie owych wymogów, co nie pozwala na uznanie, że oświadczenie to zostało złożone $\mathrm{w}$ formie aktu notarialnego ${ }^{27}$. Podobnie orzekł Sąd Apelacyjny w Krakowie w wyroku z dnia 22 maja 2002 roku, z którego wyni$\mathrm{ka}$, że dla zachowania tej formy oświadczenia woli konieczne jest wymienienie w akcie notarialnym rzeczywistego imienia i nazwiska osoby składającej oświadczenie (art. $92 \S 1$ pkt 4 u.p.n.). Naruszenie tego wymagania powoduje, iż oświadczenie osoby działającej pod fałszywym nazwiskiem nie jest złożone w formie aktu notarialnego, a w konsekwencji dokonana przez nią czynność prawna jest nieważna (art. $73 \S 2$ zd. 1 k.c. $)^{28}$.

Należy dążyć jednak do tego, żeby akt notarialny nie stracił swej ważności, zwłaszcza, gdy chodzi o uchybienia mniejszej wagi. W orzeczeniu z dnia 11 września 2013 roku Sąd Najwyższy podnosi zagadnienie tzw. wymagań porządkowych aktu, do których zalicza wskazanie przez notariusza w akcie powodu, dla którego uczestnik czynności notarialnej aktu nie podpisał, stosownie do art. $92 \S 2$ u.p.n., to jest w przypadku, gdy taka osoba podpisać się nie może lub nie umie), nie pozbawia aktu notarialnego cech dokumentu urzędowego i nie ma znaczenia dla oceny ważności lub skuteczności albo ustalenia treści czynności prawnej objętej aktem notarialnym ${ }^{29}$. Z kolei w postanowieniu z dnia 9 września 2011 r., Sąd Najwyższy stwierdził, że wpisanie obok tuszowego odcisku palca testatora jego imienia i nazwiska oraz umieszczenie podpisu przez osobę, która nie była obecna przy sporządzaniu aktu jest uchybieniem skutkującym niezachowanie formy aktu notarialnego wymaganej w art. $950 \mathrm{kc}$, a w konsekwencji prowadzi do nieważności objętej

\footnotetext{
27 Wyrok Sądu Apelacyjnego w Katowicach z dnia 8 stycznia 2014 roku, I Aca 401/12, LEX nr 1425407.

${ }^{28}$ Wyrok Sądu Apelacyjnego z dnia 22 maja 2002 roku, I ACr 299/02 , LEX nr 142150.

${ }^{29}$ Wyrok Sądu Najwyższego z dnia 11 września 2013 roku, III CSK 5/13, LEX nr 1408183.
} 
nim czynności prawnej ${ }^{30}$ Sąd Najwyższy często zresztą wypowiadał się na temat ważności testamentów notarialnych. W uchwale z dnia 19 lipca 2001 r. SN orzekł, iż nieważny jest testament osoby głuchej lub głuchoniemej, jeżeli w treści sporządzonego przez notariusza dokumentu brak wzmianki o dopełnieniu przez niego obowiązku przekonania się, że treść dokonanej czynności jest dokładnie znana i zrozumiała dla testatora (art. $87 \S 1$ pkt 2 u.p.n. w zw. z art. $92 \S 3$ u.p.n. $)^{31}$.

Jeżeli akt notarialny, zgodnie z art. 93 u.p.n. jest sporządzony na dwóch lub więcej arkuszach, to arkusze te powinny być ponumerowane, parafowane i połączone. Na zakończenie tej tematyki przywołać należy jeszcze art. $94 \S 1$ u.p.n., zgodnie z którym akt notarialny przed podpisaniem powinien być odczytany przez notariusza lub przez inną osobę w jego obecności. Przy odczytaniu aktu notariusz powinien się przekonać, że osoby biorące udział w czynności dokładnie rozumieją treść oraz znaczenie aktu, a akt jest zgodny z ich wolą. Na żądanie powinny być odczytane również załączniki do aktu. § 2 tego artykułu stanowi zaś, że wszelkie wywabiania i wyskrobywania są niedopuszczalne; wolne miejsca powinny być przekreślone, a poprawki należy omówić na końcu aktu przed złożeniem podpisu przez osoby biorące udział w czynności lub przed złożeniem podpisu przez notariusza, jeżeli poprawka dotyczy aktu niepodpisywanego przez strony. Zbędne wyrazy albo ich części powinny być przekreślone w ten sposób, aby można je było odczytać, a przekreślenia te należy na końcu aktu omówić przed złożeniem podpisów. Przekreślenia nieomówione uważa się za niedokonane.

Podsumowując regulację tego artykułu, nietrudno zauważyć, że zarówno procedura czynności notarialnej dokonywanej w formie aktu notarialnego, jak i treść będącego jej rezultatem dokumentu są dość mocno sformalizowane. Ta problematyka była niejednokrotnie przedmiotem analizy przez Sąd Najwyższy, który z reguły wypowiadał się w duchu rygorystycznego przestrzegania ,,procedury notarialnej”. Dla przykładu przytoczę wyrok Sądu Najwyższego z dnia 1 września 2004 roku, w którym stwierdzono, iż wcześniejsze udostępnienie stronom projektu aktu i skonsultowanie $\mathrm{z}$ nimi pojawiających się na tym etapie wątpliwości nie zwalnia notariusza od rygorystycznego przestrzegania obowiązku odczytania każdego aktu indywidualnie. Niezależnie bowiem od liczby konsultowanych ze stronami projektów umowy i dokonanych w trakcie tych konsultacji uzgodnień, aktem notarialnym staje się tylko ta wersja, która ostatecznie została im przez notariusza (bądź jego zastępcę) odczytana i po upewnieniu się, że odpowiada ona porządkowi prawnemu, nie narusza słusznych interesów stron i innych osób jak też, że jest dla stron zrozumiała i odpowiada ich zamierzeniom, zostaje przez nie przyjęta i podpisana ${ }^{32}$.

Również, jak wynika z wyżej powołanego przepisu, sama technika nanoszenia poprawek w treści aktu jest dokładnie uregulowana. Ma to zapewne zapobiec wszelkim próbom ingerencji w sporządzony już dokument bez wiedzy uczestników czynności i znacznie utrudnia, czy wręcz uniemożliwia modyfikację dokumentu po jego podpisaniu. Ten formalny proces powstawania aktu notarialnego, jest moim zdaniem niezbędny do jego zaistnienia jako dokumentu urzędowego i w związku z tym akt notarialny budzi duże zaufanie społeczne. W tym miejscu dodam jedynie, że opisana przez mnie regulacja raczej spełnia swoje zadanie w praktyce, a akt notarialny cieszy się dużą wiarygodnością i właśnie zaufaniem jego uczestników, jak i osób trzecich. Dla uzasadnienia tego stanowiska

\footnotetext{
${ }^{30}$ Postanowienie Sądu Najwyższego z dnia 9 września 2011 roku, I CSK 248/11, LEX nr 1043961.

${ }^{31}$ Uchwała Sądu Najwyższego z dnia 19 lipca 2001 roku, III CZP 36/01 , LEX nr 48091.

${ }^{32}$ Wyrok Sądu Najwyższego z dnia 1 września 2004 roku, SDI 37/04, LEX nr 568846.
} 
wspomnę często pojawiające się w praktyce przykłady sporządzania aktów notarialnych na życzenie klientów, choć przepisy nie stawiają w danym przypadku takiego wymogu. Również niektóre urzędy i inne instytucje „łaskawszym okiem” patrzą na dostarczane przez interesantów dokumenty, najczęściej chyba pełnomocnictwa, udokumentowane aktem notarialnym. Jest to niewątpliwie zjawisko pozytywne i potwierdzające zarówno wysoką pewność samego dokumentu, jak i zaufanie do wiedzy i stanowiska sporządzającego go notariusza. Jak natomiast daleko idące konsekwencje powoduje użycie tej wiedzy przez osoby do tego niepowołane w złej wierze, może stanowić przykład, na szczęście rzadko występujących, choć bardzo nagłaśnianych przez media procederów fałszowania dokumentów notarialnych (np. pełnomocnictw do sprzedaży „opuszczonych” nieruchomości) i dokonywanie na ich podstawie czynności prowadzących do zbycia de facto cudzej nieruchomości. Zaistnienie takiej sytuacji jest ogromnym zagrożeniem dla bezpieczeństwa obrotu nieruchomościami, a przywrócenie stanu poprzedniego może być później bardzo utrudnione i z pewnością będzie wymagało żmudnego procesu przed sądem.

\section{OBOWIAZZKI NOTARIUSZA A BEZPIECZEŃSTWO OBROTU}

Notariusz ma wiele obowiązków, które zakotwiczone są w ustawie Prawo o notariacie. Są to obowiązki o charakterze ustrojowym. Zgodnie z art. 15 u.p.n., przy powołaniu notariusz składa wobec ministra sprawiedliwości (lub prezesa właściwego sądu apelacyjnego, upoważnionego przez ministra sprawiedliwości) ślubowanie, którego treść zawiera $§ 2$ tego przepisu. Akt ślubowania związany jest $\mathrm{z}$ uruchomieniem kancelarii $\mathrm{w}$ związku $\mathrm{z}$ objęciem urzędu przez notariusza. Do ślubowania notariusza odnosi się również art. 17 u.p.n., z którego między innymi wynika, że notariusz jest obowiązany postępować zgodnie ze złożonym ślubowaniem. W rocie ślubowania notariusz zobowiązuje się powierzone mu obowiązki wypełniać zgodnie z prawem i sumieniem, dochować tajemnicy państwowej i zawodowej, w postępowaniu swym kierować się zasadami godności, honoru i uczciwości. A. Oleszko uważa, że nie chodzi o przestrzeganie treści ślubowania tylko przy wykonywaniu czynności notarialnych, ale także o zachowanie notariusza poza pełnieniem funkcji zawodowych, a nawet w życiu prywatnym ${ }^{33}$.

Jak to wynika $\mathrm{z}$ art. $26 \S 1$ u.p.n., notariusze tworzą samorząd notarialny. $\mathrm{Z}$ kolei na podstawie $\S 3$ art. 29 u.p.n. w walnym zgromadzeniu jest obowiązany uczestniczyć każdy notariusz należący do danej izby. Treść tych przepisów świadczy o tym, że przynależność do samorządu zawodowego oraz uczestnictwo $\mathrm{w}$ walnym zgromadzeniu izby są obowiązkowe, zaś w innym organach - stanowią uprawnienie notariusza. Ta regulacja pozwala notariuszowi aktywnie uczestniczyć w pracy samorządu, a drugiej strony - może mieć wpływ na ocenę postawy notariusza jako członka tego zgromadzenia. Z przynależnością do samorządu zawodowego ściśle łączy się kolejny obowiązek notariusza. Otóż zgodnie $\mathrm{z}$ art. 23 u.p.n., notariusze opłacają, na potrzeby organów samorządu notarialnego, składki miesięczne, których wysokość ustala corocznie Krajowa Rada Notarialna. Ponadto, stosownie do uchwał właściwych izb notarialnych, notariusze opłacają składki na inne określone cele. Innym, bardzo ważnym w świetle tematyki przedstawionej w niniejszym opracowaniu obowiązkiem notariusza jest obowiązek zachowania tajemnicy. Jak to podkreśla A. Oleszko, wyposażenie dokumentów notarialnych w moc urzędową stanowi istotny przejaw gwarancji zapewniających bezpieczeństwo dokonywanego obrotu z udziałem

\footnotetext{
${ }^{33}$ A. Oleszko, Prawo..., s. 145-146.
} 
notariusza jako osoby zaufania publicznego. Bezpieczeństwo to oznacza, iż wymóg jawności oraz powszechności obrotu prawnego (odnosi się to zwłaszcza do jawności praw rzeczowych), a więc i dokumentów z nim związanych musi uwzględniać także obowiązek zachowania tajemnicy. Bezpieczeństwo obrotu prawnego w kontekście rozważań na ten temat obejmować powinno: zakaz wydawania oryginałów aktów notarialnych poza miejsce ich przechowywania (regulowany ustawowo, tam też wyjątki), gwarancję ochrony prywatności uczestników czynności notarialnych (głównie na gruncie ustawy z dnia 29 sierpnia 1997 roku o ochronie danych osobowych) oraz ochronę tajemnicy zawodowej notariusza. Podkreślić należy, że zarówno na tle obecnie obowiązujących regulacji ustawowych, jak i głoszonych na ich tle poglądów w piśmiennictwie, chodzi tu o zachowanie tajemnicy służbowej państwowej, jak i zawodowej notariusza, zwanej również tajemnicą notarialną ${ }^{34}$. Do innych obowiązków notariusza należy respektowanie zakazu łączenia stanowisk oraz podejmowania innego zatrudnienia (bez zgody organów samorządu notarialnego) oraz zakaz reklamy zawodowej oraz nieuczciwej konkurencji zawodowej.

\section{ODPOWIEDZIALNOŚĆ NOTARIUSZA}

Notariusz może ponosić różne rodzaje odpowiedzialności w różnych sytuacjach, np. odpowiedzialność karną, cywilną czy karno-skarbową. W ramach tego opracowania jednak chciałabym skupić się na odpowiedzialności dyscyplinarnej jako na swoistej, dodatkowej odpowiedzialności, mającej swoje zakotwiczenie w ustawie prawo o notariacie. Otóż zgodnie z art. 50 u.p.n., nawiązując do zawartych w nim odesłań, notariusz odpowiada dyscyplinarnie za przewinienia zawodowe, w tym za oczywistą i rażącą obrazę przepisów prawnych, uchybienie powadze i godności zawodu oraz za niedopełnienie obowiązku zawarcia umowy ubezpieczenia. Art. $51 \S 1$ u.p.n. wymienia z kolei te kary: upomnienie, nagana, kara pieniężna w wysokości w nim wskazanej oraz pozbawienie prawa prowadzenia kancelarii. Nie wchodząc szczegółowo w rozważania teoretyczne nad tym zagadnieniem, pragnę jedynie dodać, iż jest to kolejny, bardzo ważny element weryfikacji pracy notariusza pod kątem zgodności z obowiązującymi go przepisami i umożliwia stworzenie pewnego standardu pracy zawodowej rejentów wewnątrz własnej korporacji. Sprzyja też ukazywaniu i eliminowaniu zachowań niepożądanych, szkodliwych zarówno dla korporacji zawodowej, jak i dla osób trzecich, w tym przede wszystkim klientów kancelarii notarialnych.

Na uwagę zasługuje również fakt, że notariusze mają własne, ,wewnętrzne” sądownictwo dyscyplinarne oraz procedurę postępowania przed sądami dyscyplinarnymi, uregulowane w prawie o notariacie. $\mathrm{Z}$ tym zagadnieniem, w moim odczuciu, zazębia się nieco kwestia etyki zawodowej notariusza. Notariuszy obowiązuje kodeks etyki zawodowej notariusza z dnia 12 grudnia 1997 roku, będący uchwałą Krajowej Rady Notarialnej. Wspomniane powiązanie znajduje odzwierciedlenie w par. 11 pkt 2 tego kodeksu, który stanowi, iż zgodność z prawem czynności notarialnej nie wyklucza odpowiedzialności dyscyplinarnej notariusza, jeśli czynność ta została dokonana z naruszeniem zasad etyki zawodowej notariusza. Jest to podejście dość restrykcyjne, mieszczące w sobie szerokie spektrum możliwych przypadków i dlatego różnie oceniane w piśmiennictwie, natomiast rozważnie stosowane i nienadużywane, ma szansę spełnić swoją rolę wyznaczania zawodowych standardów postępowania notariuszy.

\footnotetext{
${ }^{34}$ Tamże, s. 148-162.
} 


\section{DROGA DO ZAWODU NOTARIUSZA}

To zagadnienie również bardzo ściśle powiązane jest z tematyką niniejszego rozdziału, gdyż dobrym, godnym zaufania notariuszem, może być, zgodnie z założeniem ustawodawcy jedynie osoba, która zdobędzie odpowiednie wykształcenie potwierdzone zdanym egzaminem zawodowym. Nie będę rozpisywać się szczegółowo o kolejnych etapach zawodowej drogi, chciałabym jedynie, dla niewtajemniczonych, wyjaśnić, że osoba, która chce zostać notariuszem, musi dostać się, oczywiście po ukończeniu studiów prawniczych, na aplikację notarialną (w tym celu zdaje egzamin), odbyć tę aplikację oraz pozytywnie zdać egzamin zawodowy. Szerokim echem odbiła się ostatnio przeprowadzona tzw. deregulacja, która objęła m.in. zawód notariusza. Otóż przed deregulacją tego zawodu, do powołania na notariusza, konieczne było również odbycie dwuletniej asesury notarialnej, która jest, mówiąc w uproszczeniu, niczym innym, jak wykonywaniem pracy notariusza, ale bez możliwości otwarcia własnej kancelarii, czyli będąc zatrudnionym u jakiegoś rejenta. W tym okresie, w założeniu, przyszły, zwykle jeszcze niezbyt doświadczony kandydat na notariusza, doskonalił swoje umiejętności pod okiem bardziej doświadczonego rejenta, dokonując czynności notarialnych w pełnym zakresie (włącznie z odczytaniem aktu notarialnego i podpisaniem go swoim nazwiskiem). Sama istota takiej praktyki jest, moim zdaniem, rozwiązaniem bardzo dobrym, pozwalającym powoli wdrożyć się w obowiązki rejenta, doszkolić, sprawdzić (wiem to z własnego doświadczenia). Niestety, wadą tak skonstruowanej asesury jest możliwość wykorzystania jej jako czynnika ograniczającego dostęp do zawodu (sama wola notariusza, czy chce zatrudnić asesora jest decydująca, na nie ma on takiego obowiązku), a już na pewno w sytuacji, w której stosunkowo dużo osób kończy aplikację i pomyślnie zdaje egzamin zawodowy. Tak też była niewątpliwie ta instytucja postrzegana „na zewnątrz”, w związku z czym w ramach wspomnianej przeze mnie deregulacji, wymóg odbycia asesury został zniesiony. Na jego miejsce wprowadzono możliwość zatrudnienia się, po zdaniu egzaminu notarialnego, jako zastępca notarialny, na warunkach zbliżonych do asesury.

\section{Literatura}

1. Gniewek E., Kodeks cywilny. Ksiegga druga. Wtasność i inne prawa rzeczowe. Komentarz (do art. 158 kodeksu cywilnego), LEX 73505.

2. Kuryłowicz M., Chirographa i syngrapha, „Rejent” 1994, nr 10.

3. Oleszko A., Prawo o notariacie, Warszawa 2016.

4. Piasecki K., Kodeks cywilny. Komentarz. Księga pierwsza. Część ogólna, LEX nr 77375.

5. Truszkiewicz Z., W sprawie przyszłości notariatu - kilka refleksji, „Rejent”, marzec 2013.

6. Urbanik A., Reprywatyzacja notariatu 2011, „Rejent”, listopad 2011 (jubileusz 20-lecia miesięcznika, wydanie specjalne).

7. Skrzydło W., Konstytucja Rzeczypospolitej Polskiej. Komentarz, LEX nr 144810.

\section{Akty prawne}

1. Konstytucja Rzeczypospolitej Polskiej z dnia 2 kwietnia 1997 r. (Dz.U. nr 78, poz. 483 ze $\mathrm{zm}$.).

2. Ustawa z dnia 1 stycznia 1965 r. Kodeks cywilny (Dz.U. z 2014 r., poz. 121 ze zm.).

3. Ustawa z dnia 14 lutego 2014 roku Prawo o notariacie (Dz.U. z 2014 r. poz. 164 ze zm.). 


\section{Orzecznictwo}

1. Postanowienie Sądu Najwyższego z dnia 9 września 2011 r., I CSK 248/11, LEX nr 1043961.

2. Postanowienie Sądu Najwyższego z dnia 12 marca 2013 roku, SDI 3/13, LEX nr 1418779

3. Wyrok TK z dnia 10 grudnia 2003 r., K 49/01, OTK ZU 2003 nr 9a, poz. 101

4. Wyrok Sądu Apelacyjnego w Katowicach z dnia 8 stycznia 2014 r., I Aca 401/12, LEX nr 1425407.

5. Wyrok Sądu Apelacyjnego z dnia 22 maja 2002 r., I ACr 299/02, LEX nr 142150.

6. Wyrok Sądu Najwyższego z dnia 1 września 2004 r., SDI 37/04, LEX nr 568846.

7. Wyrok Sądu Najwyższego z dnia 11 września 2013 r., III CSK 5/13, LEX nr 1408183.

8. Uchwała SN z dnia 2 grudnia 1994 r., III CZP 152/94, OSNC 1998, nr 5 poz. 76.

9. Uchwała Sądu Najwyższego z dnia 19 lipca 2001 r., III CZP 36/01, LEX nr 48091.

\section{NOTARIUS AS A GUARANTEE FOR SAFETY OF REAL ESTABLISHMENT}

The notary profession is a profession of public trust and the person performing this profession is obliged to respect the highest ethical standards and be beyond any suspicion as to their impartiality, which entitles to sanctioning any behavior, posing at least the risk of undermining that trust. While performing his duties, he supervises the security of legal transactions in real estate and in this respect he is treated as the so-called "A person of public trust". The notary does not act as a mandate of any of the parties to the notarial act. A notary is the only profession that does not have the status of a civil servant whose activities are lawfully carried out in the form of an official document, but none of his documents is his property and they are state property, and the notary only has the obligation to store and secure them. A notary does not provide typical legal services, such as a lawyer, legal advisor or tax advisor, and therefore he does not combine the legal relationship with the contractual relationship. The question then arises as to whether a notary public as a professional can be a guarantor of security during real estate transactions. Security in fact gives the individual certainty, although some risk of danger is included in each of the legal professions. Therefore, the legislator created such legal solutions to eliminate the risk of exposure to any damage to a potential notary client or his property in full or significant terms.

Keywords: notary, security, real estate, security guarantee, real estate trade.

DOI: $10.7862 /$ rz.2018.mmr.8

Tekst ztożono $w$ redakcji: luty $2018 \mathrm{r}$.

Przyjęto do druku: marzec 2018 r. 